\title{
Amidst tongues tearing apart and lying lips, God of and for the oppressed: Casting an African gaze at Psalm 12
}

\author{
Masenya, Madipoane \\ University of South Africa \\ mwmapoan@mweb.co.za
}

\begin{abstract}
If there is any piece of literature that seems to be time-less, allowing each reader from different cultural contexts and time periods to break through it, it is the Psalter. Also, the struggle by the scholars to lay handle on the origins of the individual lament/complaint psalms may prove affirming to those, who on account of their marginal status, could be "barred" from reading the psalms informed by their own marginal status ${ }^{1}$. Psalm 12 seems to defy clear categorization both as an individual or a communal lament. Like others, it is a psalm that critiques the abusive use of the human organs that enable speech that is, the tongue and the lips. Particularly when the preceding organs are used by the powerful (read: the rich) to despoil the poor and needy, YHWH, the God, of and for the oppressed gets roused and acts in their favour! If re-read African-consciously, what kind of reading may Psalm 12 yield?
\end{abstract}

Key words

Psalm 12; tearing-apart tongues; lying lips; African context; the poor and the needy

1 Brueggemann (1986), Goldingale (2006:24-25), and Carleen Mandolfo (2014:114-130) are of the opinion that the fact that the origins of the lament psalms remain a mystery enables them to be applied to different situations throughout of history. 
...most of the Psalms can only be appropriately prayed by people who are living at the edge of their lives, sensitive to the raw hurts, the primitive passions, and the naïve elations that are at the bottom of our life. For most of us, liturgical or devotional entry into the Psalms requires a real change of pace. It asks us to depart from the closely managed world of public survival, to move into the open, frightening, healing world of speech with the Holy One. (Brueggemann1986:20)

Songs constitutes a rich heritage for the whole of Africa. For Africans are always singing and in their singing and poetry, they express themselves. In this way, all their joys and sorrow, their hopes and fears about the future, find an outlet (Idowu1965:84).

\section{Psalm 12}

${ }^{1 .}$ Help, Lord, for the godly man comes to an end, for the faithful disappear from sons of men.

2. They speak empty words, each with his own neighbour; they speak with flattering lips and a double heart.

3. The Lord will cut off all flattering lips, and the tongue that speaks proud things,

4. who have said, "With our tongue will we prevail; our lips are in our control, who is master over us?"

5. "Because the poor are plundered, because the needy sigh, now I will arise," says the Lord; "I will place him in the safety for which he yearns."

6. The words of the Lord are pure words; they are silver tried in an earthen furnace refined seven times. You will keep them, O Lord;

7. You will preserve them from this generation.

8. The wicked walk on every side, when the worthless of mankind are exalted. 


\section{Introduction}

In the context of the history of Bible interpretation in the church in Africa, it could be argued that if there is any popular biblical book within the Christian Bible, whether within varying African church contexts ${ }^{2}$ or elsewhere, it is the Psalter. This is the case because as Brueggemann has rightly argued," ...most of the Psalms can only be appropriately prayed by people who are living at the edge of their lives, sensitive to the raw hurts, the primitive passions, and the naïve elations that are at the bottom of our life."(1986:20) It may also be argued with Adamo that African Christians, especially those within the African Independent Churches feel drawn to the Psalter because of the perceived points of resemblances between the Israelite and African worldviews ${ }^{3}$ and the firm belief of the Psalms' capacity to address various challenges in believers' lives. Does it then occasion any wonder that a psalm like Psalm 12 could be designated differently, depending on a particular author's social location and or specific agenda? The following examples can serve as cases in point: On the one hand, John Goldingay classifies Psalm 12, together with other psalms like Psalms 44, $60,74,79,80$ among others, as protests for the congregation. On the other hand, David T. Adamo classifies Psalm 12, with many other psalms like Psalms 1, 2, 4, 5, 51, 53, 55, 64, 72, 74, 121, 130 and 147 among others under the heading "Psalms as Potent Words for Protection."(Adamo2004:151).

As a matter of fact Adamo, has to my knowledge, more than any other African Hebrew Bible on the continent, dedicated a significant amount of his time to the Psalter within an African context such as the Nigerian one.

2 Elsewhere, Masenya (ngwan'a Mphahlele) says, "Within our ecclesiastical settings, it is not uncommon for one to "hear" some of the psalms or texts derived from Psalms sung as hymns and/ or choruses. The hymn Ke na le Modisa, ke tla be ke hloka eng, literally, The Lord is my Shepherd, what (more) do I need? comes to mind here. In times of distress when the community mourns the loss of loved ones for example, the words of Psalm 23 come in handy, to soothe and to reassure the bereft families of God's care through (prayerful) songs. Within such settings, the psalms also form an important content of the believers' prayers. Perhaps in that way, one would not be exaggerating to argue that more than any book in the Christian Scriptures, the Psalms live in the veins of many an African Christian for whom the Bible remains the norm."

3 Argues Adamo, "We African Christians searched the Bible time and again with our own eyes to see whether it could help us to solve our particular problems. In the process we discovered in the Bible a worldview and culture that has great affinities with our own..."(2004:151) 
He has shown in several of his works how rooted, the book of Psalms is in African Christianity.

According to Adamo,

African Indigenous Christians sought vigorously for that hidden treasure in the missionary religion that was not revealed to them. They sought it in the Bible, using their own cultural interpretive resources. Using Yoruba cultural hermeneutics to interpret the Bible, they found that there was (and is) a secret power in the Bible, especially in the book of Psalms, if it is read and recited at the right time, in the right place and a certain number of times.

(Adamo2001: 339)

The believers believe in the potent words of the psalms to effect specific forms of healing, to bring prosperity and to offer protection among others. Adamo in a way justifies the use of such a hermeneutics by referring to the examples of Jesus and some of the Old Testament prophets (2004:161). In order to promote healing, protection and success in life, they used potent words, prayers, touching, water and material means. ${ }^{4}$ It is no wonder that elsewhere Adamo challenges outsiders to the African status quo to allow African Christianity to be shaped by the experiences of African peoples 5 (Cf also Adamo 2010: 230-236).

My engagement with Psalm 12 in this article, is also shaped by the history of how the Bible has been used by various Black and liberation theologians, especially here in South Africa. They has used the Bible as a weapon against life-denying forces which revelled and still revel, at pushing the poor and needy to the margins. What I find interesting though, is that albeit the Psalter has been and continues to be a popular book within African Christian churches in South Africa, it has not, unlike the book of Exodus

4 Luther's interpretation of Psalm 8 within the context of the prophecies about Christ would perhaps make more sense to Adamo (Pak 2005:171).

5 In his advocacy for what he calls "Afrocentric methods of interpretation" he says" "Because Western methods of interpretation are not the only legitimate and universal methods, and since all interpretations are contextual (including Western interpretations), African biblical scholars should acknowledge the legitimacy of this type of African interpretation and encourage this interpretation with some possible modification"(2004:161-162). 
and some texts from the prophetic corpus (cf Micah by Itumeleng Mosala) received attention as part of protest literature. The present engagement will hopefully add to the existing literature on liberationist biblical hermeneutics, albeit based on the Psalter.

\section{The tongue: A small, but potent organ}

O na le leleme, literally, "s/he has a tongue" is an idiomatic expression that depicts a person who not only has the capacity not to keep quiet, but one with a tongue that bites. Such is a tongue that is geared at disrupting and destroying what is good. It is a tongue that causes and thrives in chaos. It is a tongue which is at odds with justice and all justice-seeking acts. It can thus bring chaos to the lives of those on the margins, throwing such lives furthest on the margins.

Another expression, o na le leleme le boreledi depicts a person who has a smooth tongue. At face value, one can be deceived by the idiomatic expression into anticipating that a smooth-tongued person will use it to create calm, peace and well-being. To the contrary, a smooth-tongued person excels in deceit. As a matter of fact, his/her speech is a direct contrast to what he/she thinks. O bolela ka leleme la maphakga, he/she speaks with two tongues. According to the psalmist, such a person speaks a double heart, literally heart and heart (Murphy2000:76; (beleev valeev; cf.Ps12:3 in the MT). ${ }^{6} \mathrm{~A}$ smooth tongue works hand in clove with lying lips! $!^{7}$ One is here reminded about a controversial statement which was made a few years ago by one of the South African premiers, "All politicians are liars."

Those who possess such tongues tend not only to be arrogant, they idolise their speech organs - their tongues and their lips. The preceding organs

6 Reasons Cyril Okorocha (2006:620): "By contrast, the Bible calls us to serve God with one heart, that is, single-mindedly (Jer 32:39; Ezek 11:19-20; Acts 4:32)" "Psalms," Africa Bible Commentary, Tokunboh Adeyemo(ed) 605-746, Nairobi: WordAlive Zondervan Publishers. See also his argument that the word of God is inserted elsewhere in Psalm 12 just like in the following texts: 50:5, 7-23; 81:6-16; 95:8-11)

7 Goldinggay reasons: "Their words are smooth - they are nice, bringing good news, gliding easily down the throats of their recipients, who are glad to receive them... But the speakers are double-minded-a paradoxical way of saying that they seem and purport to think and intend one thing, but in their ${ }^{*}$ minds they think and intend something quite different. They are not people of one heart and one way (Jer. 32:39), whose inner and outer life cohere." (2006:198) 
become the source of their pride; “"With our tongue will we prevail; our lips are in our control, who is master over us?" (Ps12:4 MEV). Could it be that by the preceding utterance, they are in fact denying the existence of God? (cf Goldingay2006:199)? ${ }^{8}$ Perhaps the powerful in charge here are the most to be pitied as they are ironically controlled by a tongue, a very small organ.

One who owns a boastful tongue seems to have forgotten the truth underlying the following Northern Sotho/Sepedi proverb: $O$ se bone go akalala ga bonong, go wa fase ke ga bona literally translated as "do not mind the soaring so high of an eagle, he/she will soon fall down." Indeed pride does go before a fall, and in line with the prayer of the psalmist, it must go before the fall because: "The LORD will cut off all flattering lips, and the tongue that speaks proud things..." (Ps12:3 MEV). Indeed, God of, and for the oppressed, will intervene on their behalf. Depending on a reader's context, the preceding prayer/wish might appear ruthless, but for those living at the edge of their lives, such a prayer may be found to be empowering according to Mandolfo:

From a privileged Euro-North American point of view, these expressions are understandably distasteful. It is all too easy however, to take a superior attitude toward these "crude" expressions of anguish. From the point of view of the perennially downtrodden, such expressions seem a rather healthy attempt to reclaim some semblance of control over their lives (Mandolfo2014:124)

\section{Structure of the lament / complaint}

\section{Charting the setting of the Psalm: The addressee?}

The setting displayed by Psalm 12 is that of an interaction between the prayer / psalmist (and/or his/her community) and the deity. The object to whom the complaint is directed is YHWH, the God of Israel. The local nature displayed by the contents of the psalm is thus to be noted. Although some of the generic words used in the opening lines might give an impression

8 "They are saying that there is no lord ('ādôn) but them, thus implicitly denying God's existence."(Goldinggay2006:199) 
of a universal outlook, the psalmist's focus seems to be on the insiders who knew exactly what the life of godliness and faithfulness entailed. The addressees were thus well conversant with the fact that YHWH took sides with the poor and the needy. Worthy of note is the connectedness between the words ani and anaw/anawim, ebyon and dal. These words are used to depict those on the margins, the poor, the needy, the helpless and the downtrodden. These are the marginalised, economically and "spiritually poor". For Groenewald, the words ani and anaw can be appropriated to those who are humbled through all kinds of material oppression. ${ }^{9}$ If the psalm was addressed to outsiders to Israel's faith, on which grounds would he have held the non-Israelites accountable for having broken their relationship with YHHW, the national God of Israel? The confidence and openness through which the psalmist approaches God thus also reveals something of this close relationship between him and his people and the deity. The male psalmist can thus not buy into the African notion that monna ke nku o llela teng, a man is a sheep, he cries inwardly. Within a well-contained, ordered and controlled patriarchal setting, the Psalmist's masculinities might be deemed soft if not problematic. ${ }^{10}$ How could he get distressed by what other fellow men, perhaps as powerful as he was, were doing? ${ }^{11}$ Not so with the present justice-seeking prayer. He is not afraid to cry: "Help"! He is concerned with the abuse of power by those who care less about the plight of the poor and needy. Not only does the opening lines/ or the approach of the psalmist to the deity throw light on his close relationship with the deity. As already noted, particularly the opening line, gives readers an impression that the whole community (to which the psalm is addressed) had/ or is expected to have had a relationship with God. That was however not the case. The godly are no more! The faithful have vanished

9 In his article, "Psalm 69:33-34 in light of the poor in the Psalter as a whole" Alfonso Groenewald engages these words in a convincing way. In his view, the words ani and the anaw, words which can be used interchangeably, to refer to those who are humbled through all kinds of material and spiritual poverty.

10 This means that the agenda and intention of the Psalms is considerably at odds with the normal speech of most people, the normal speech of a stable, functioning, selfdeceptive culture in which every-thing must be kept running young and smooth (Bruegemann1986:19).

11 Refer the view of commentators who argue, based on the connections between some of the contents of the psalm to some texts from the book of the prophet Habakkuk, that the speaker could have been one of the cultic prophets. 
and the absence of godly faithful men is replaced by the presence of biting, destructive and lying tongues. Sclater observes the appropriateness of the order here: "Implicitly they are the ungodly and the untrue, and their sign is flattering lips. There is significance in the sequence: ungodliness produces inner untruth, which produces as its overt fruit plain lying. Forget God, and you get a society in which men (sic) trust each other, and which therefore must ultimately collapse (1955:69). The effects of the works of such tongues are marked on the bodies of the powerless, the poor, and the weak ${ }^{12}$. As Hayes has rightly observed: "When faithfulness wanes and wickedness waxes, the poor and needy suffer; they are left without support or advocate (v.5)" (Hayes1989:77) .The lament over the prevalence of wickedness may also suggest the prophetic nature of the psalm (Isa57:1-13; 59:1-21; Jer5:1-3; Hos4:1-3; Mic7:1-7 (McCann1993:724). Literally, our lips (and not God) are with us. In their minds, they are accountable to themselves.

\section{Description of distress}

What is at stake? Who are the perpetrators? Who are the objects of the psalmist's fury, wrath, and frustrations? What exactly are they doing? The last question has already been attempted to, in the preceding paragraphs. Depending on a particular Sitz im Leben, possibilities abound. In the preexilic setting, the objects of scorn could have been the Empires that were constantly a threat to the people of God. Or better still, as already noted, the Psalmist might have been concerned about what was happening at home, that is, within Israel. The content of the complaint might as well have been an act of self-introspection, a critique of the leaders (both political and religious) of his day. During the era of the eighth century prophets, for example, it was common place for the political leaders who were out of line with God's will, to work hand in glove with false prophets. The unsuspecting masses, who were equally out of line with YHWH's will for their lives, could be fed the lies from the double, smooth tongues of both the priests, prophets and kings. In the process, the poor and needy became the hardest hit.

12 Clifford (2002:83) argues that the poor and needy are used in parallel verses to refer to economic poverty and the powerless state which arise out of lack of resources. It could refer to those left defenceless when the righteous retreat (v.1) and the arrogant attack(vss2-4) (2002:83) He argues that it is precisely on account of their need that God is roused to act on their behalf 
If we posit a setting in post-exilic Yehud, ${ }^{13}$ a context in which the Hebrew Scriptures took shape, one in which there was a struggle to maintain a solid Jewish identity of a people whose lives were centred on the cult and all its expectations, the acute frustrations of the psalmist about the ungodly and unfaithful lives would make more sense. With the Jews still under Empire and all (the power) that goes with it, there were some of the leaders who had on account of greed for example, chosen to stay faithful to their cravings for power and greed, at the expense of the poor and the needy: Ceresco notes the gap between the small landowners and farmers, on the one hand, and the rich aristocratic class, on the other. "This wealthy minority" argues Ceresco

...was composed of foreign officials based in the country itself or elsewhere. It also included their upper-class Jewish agents and collaborators. Many small farmers and their families were dispossessed of their properties. At the same time, the wealthy elite accumulated even larger tracts of land for themselves and/or as agents of foreign ruling powers, first of Persian, then of Ptolemaic kings and nobles. The dispossessed farmers and sheepherders now worked the land as tenant farmers and day labourers

(Ceresco2005:92)

Could it be that the psalmist was among the powerful rich who chose to lead godly and faithful lives, hence his concern about the plight of the poor and the needy?

Or, could it be that the prayer was probably one of the priests or prophets who was determined on challenging the corrupt status quo? Given the relatively lower position of the Levitical priests as compared to the Aaronite priests, the appreciation of the Levites for the plight of the poor and needy, could make sense. De Claisse-Walford argues that "The Levites would be

13 Regarding the post-exilic dating of the psalm, Taylor contends: "The psalm is a protest against the lax ways of a generation which set little store by the homely virtues of honesty and sincerity in speech and manners. It is therefore concerned with social aspects of social conduct toward which later Judaism as represented by the wisdom literature was giving increasing attention. Altogether, then, the seeming remoteness of the psalmist from the living voice of prophecy, and the special moral interest which has in common with some wisdom writers possibly lead us to date the psalm in the postexilic period (cf. 73:4-20; Prov. 6:16-19; 8:6-9; Ecclus. 4:20-31; Pss. Sol. 12:5.”(Taylor1955:69). 
the most likely group within the post-exilic community to collect, preserve, and 'shape' the normative and authoritative songs of Israel's cult into the Psalter. They perhaps would have been a little closer to the common people and would have understood and reflected the hermeneutical foundations which underpinned the postexilic community." (1997:28). Broadly speaking though, given the relatively "low" position of the nation of Israel as a subject of the Persian Empire, an average Jew would have had a feel of what it meant to be on the periphery. One is here reminded of Sneed's remarks about Qoheleth's class. In Sneed's view, Qoheleth reveals both elitism and less-than-aristocratic concerns, values and ideas "...he should be viewed as occupying the lowest rung of the aristocracy, a member of the retainer class, which served the higher aristocrats yet shared their privileged lifestyle, though not to the same degree."(2012:141)

Could it be that he is not only the voice of the poor par excellent, but that he was actually part and parcel of the poor and the needy? Whoever the Psalmist was, he was someone with a voice. In my view, the prayer was someone with some measure of power. ${ }^{14}$ Like many other psalmists, he seems to have always been on the right side of the law of YHWH (or so he thought), hence the confidence with which he laments the disappearance of the godly and the faithful (Ps12:1). It is also noteworthy that there seems to have been a consistent simplistic assumption that the poor and needy were in a right relationship with God while the enemy of the psalmist were almost always evil. J. Clinton McCann Jr. reasons: “...in the larger perspective of the Psalter, the existence of a suffering Messiah (cf David in Part I of the corpus) (and the pervasive suffering of "the righteous," who normally are the prayers

14 Mandolfo reasons that "These (the supplicants) are not authority figures flexing their muscles against the weak but rather the vulnerable and powerless exercising the only agency left to them, namely, their imaginations"(2014:123) Language of Lament in Psalms, 114-121 in the Oxford Handbook of the Psalms, edited by William P. Brown, Oxford University Press: Oxford. In a more or less similar vein, although Brueggemann argues for Psalm9-10, he contends that the cluster of words (some of which appears in Psalm 12), oppressed (dak, v. 9), the "poor, afflicted" ('anawim or 'aniyyim, vss 12, 18), the one who suffers "'oni, v.13) and the needy "'ebyon, v.18) makes clear that the speaker and those for whom he represents are those marginal and socially vulnerable (in the face of the enemy). (1995:220). Brueggemann, Walter (edited by Patrick D. Miller), The Psalms \& the Life of Faith, Minneapolis: Fortress Press. Groenewald elaborates on the notion of the piety of the poor as developed by Albertz during this time in Jewish history. As already noted, one would amend the phrase "vulnerable and powerless" in the preceding phrase to read "the relatively, vulnerable and powerless". 
in the body of the psalms assigned to David) suggests that sovereignty, happiness, and refuge are not mutually exclusive with suffering." (2014:353).

Clifford reminds us of the time-less/timely nature of the contents of Psalm 12 when he reasons:

"The psalm more likely describes something more limited in scope and closer to our own experience: occasions when cooperate behaviour or greed or cowardice silenced the gospel so that those who upheld it found themselves isolated and unable to live a common and public life. For this kind of "minority" the psalm is eminently suitable. It turns to God and expects action from God who is grieved because the poor are despoiled."

(Clifford 2002:84-85)

In Africa, the complaint of the psalmist could be addressed to the Empires which have plundered the poor and needy through the ages (cf colonialism and slavery among others). Even up to this day, Empire, under the guise of neo-colonialism and globalisation continues its tendency to employ a smooth tongue to many a marginalised person inhabiting the Two Thirds World. And indeed, many an African leader continues to buy in into such smooth talks, much, to the detriment of many a poor African person. Of course they have a lot to gain from their close relationship with Empire. Ironically, many imperial subjects also continue to desperately want to be associated with Empire.

During apartheid South Africa, not only were the poor and needy plundered at the barrel of a gun, the employ of police dogs and tear gases. The apartheid regime e be e na le leleme le boreledi. The regime had a smooth tongue. Through the latter, the marginalised were told that they were created differently; that they could thus flourish so well when they lived in different ethnic Bantustans. Beneath and behind the lying and smooth tongues, the blacks were plundered of their land and its resources. Could the well-known prayer of Bible and land theft also fit into this equation? That the biblical message which was delivered as good news was intentionally delivered with a double heart (read: tongue) to plunder the poor and needy, while at the same time the immediate material benefits which could have emerged from the same message only benefitted a particular "chosen" race? 
The smooth tongues of present day politicians become more pronounced particularly during the seasons of elections. The poor and needy become inundated with tantalizing promises most of which never get to be realised. ${ }^{15}$ What is realized though, is the enrichment of the powerful while the gap between the rich and the poor continues to widen. The religious establishment, particularly the prosperity preachers within neoPentecostal and charismatic Christianity with their vain promises given to many a poor African person cannot be left out of the equation. Who but the poor and needy in present day South Africa, could have the boldness to eat snakes and rats and still feel affirmed?

Could academia also be part of the present day objects of the psalmist's vehement attack and critique? Would it be an exaggeration to argue that our pens (just like the scribal pens) which penned down Psalm 12, are actually our tongues and lips? Are the pens committed to the cause of justice for the plight of the poor and needy? Are we double-tongued in what we pen down? Is there perhaps a disjuncture between the power of our justice-seeking words and our justice-denying praxis?

\section{Plea for redemption}

"The laments have the capacity to articulate the good news of a God who makes God's own self present in the depths. This capability alone explains why the loss of the laments is so "costly." (McCann, Jr. 1993:88)

The tearing apart tongues and the lying lips of those in power have wreaked havoc. Chaos is prevailing. The powerless, that is the poor and needy have been wronged. The psalmist's appeal to the God of the poor and powerless has been made. The answer is immediate. As could be expected, God who had historically heard the groaning and moaning of the oppressed will vindicate against them because the same God who can cut down the lying lips and the flattering tongues, can also immediately promise to come to the rescue of the weak, the poor and the needy. Knowles problematizes the metaphor of God as both male and female within the Psalter. God is portrayed as both one who kills the enemy and knits together a child. The

15 The words of J Clinton McCann are on target: "We are easy prey for politicians whose simplistic slogans about prosperity and progress regularly succeed in making us forget that we live in the moist brutal and frightening era in human history..."(1993:94) 
idea of absolutizing a single metaphor for God thus becomes problematized. Yahweh is portrayed basically (but not solely) as a male God who takes care of the interests of those on the margins, the widow and the orphan. Knowles reasons,

By portraying YHWH as one invested in the plight of the powerless (either in the role of a missing male relative for vulnerable widows or of taking special care of the social and economically invisible members of society such as orphans and clients), the Psalms reflect a male-cantered society while at the same time constructing power as interest for and with the weak. (2004:427)

As already noted, the honesty and frankness with which the psalmist approaches YHWH reveals something of a close relationship between him (and his community of faith) and God. His statement of confidence in Yahweh's promise to intervene on behalf of the poor and needy is revealed by his proclamation and affirmation of the purity of the words of YHWH and YHWH's capacity to fulfil YHWH's promise: “The words of the Lord are pure words; they are silver tried in an earthen furnace refined seven times. You will keep them, O Lord" (Ps12:6). McCann Jr. can thus argue, "The God whose promises are sure, whose words are pure, is an ever present God: While God's involvement in the world does not consist of God's pulling all the strings and manipulating all the causes that make things happen, God is involved. Amid the complex, complicated, ambiguous and messy realities of our lives and the life of the world, God is present and active to fulfil ultimately God's purposes for human life and all creation. (1993:93).

Noteworthy however is the fact that the psalmist ends the Psalm both with an affirmation of God's preservation of the poor and needy as well as the continued reality of the existence of wicked men, people who in spite of their worthless ways, continue to prevail.

\section{Conclusion}

The observation that Psalm 12 is enveloped by a relatively negative and apparently pessimistic coda deserves our attention here at the conclusion. Earlier on in this article, note was made of the time-less nature of the contents of the psalms, also acknowledging the possibility of employing 
the psalms in various cultural contexts and across different time periods. The preceding application would make sense within a context where the sacred texts which contain the Psalter enjoy some authoritative status. An important question to be raised is: Could a psalm that begins and ends with the absence of godly faithful people as well as the continued entrenchment and exaltation of evil people, people who are geared at plundering the poor and needy, be found helpful to those who have nothing to hold on to, but their close relationship with the God who is proclaimed in there? Such would be those who approach the exercise of prayer not in a routinized way, but who, like the reciters of the laments of biblical Israel believe in the power of prayer. Such are the ones, who like the psalmist know that they do not have the power to handle the enemy, only God does. Argues Mandolfo: “...never do these psalms imagine the supplicant taking the matter of justice (or vengeance) into his or her own hands. It is always left to the deity (or fate) to exact retribution" (2014:123). Within the pessimistic envelope, a text which appears to be central to Psalm12 is the psalmist's conviction that God is on the side of the poor and needy, "Because the poor are plundered, because the needy sigh, now I will arise," says the Lord; "I will place him in the safety for which he yearns" (Ps12:5 MEV).

The actions of the evil doers may be overwhelming; humanly speaking there may appear no light at the end of the proverbial tunnel. However, in the view of the psalmist, it appears that a creative tension should be kept between faith and doubt. Such a tension in my view, assures him that he dares not succumb to the human temptation of attempting to take control over the situation. The tension is sustained by psalmist's unwavering conviction that God is of and for the oppressed.

\section{Bibliography}

Adamo, TD 2001. "The Use of Psalms in African Indigenous Churches in Nigeria”. In West, GO and Dube, MW (eds), The Bible in Africa: Transactions, Trajectories, and Trends, 337-349. Leiden/Boston/Köln: Brill.

Adamo, TD 2004. "Psalms" in Patte, D (ed), Global Bible Commentary, 151-162. Nashville: Abingdon Press. 
De Claisse-Walford, NL 1997. Reading from the Beginning: The Shaping of the Hebrew Psalter. Macon: Mercer University Press.

Brueggemann, W1986. Praying the Psalms. Winona, Minnesota: Saint Mary's Press.

Brueggemann, W (edited by Patrick D. Miller) 1995, The Psalms \& the Life of Faith, Minneapolis: Fortress Press.

Ceresco, AR 2005. Introduction to Old Testament Wisdom: A Spirituality of Liberation. Maryknoll: Orbis Books.

Clifford, R 2002. Abingdon Old Testament Commentaries, Psalm1-72, Nashville: Abingdon Press.

Gerstenberger, ES 2014. Non-Temple Psalms: The Cultic Setting Revisted. In The Oxford Handbook of the Psalms, edited by William P Brown, 338-349. Oxford University Press: Oxford.

Groenewald, A 2015. "Psalm69:33-34 in light of the poor in the Psalter as a whole". In Verbum et Ecclesia. Online Journal, OASIS.

Goldingay, J 2006. Baker Commentary on the Old Testament Wisdom and Psalms: Psalms, Volume 1: Psalms1-41; Grand Rapids: Baker Academic.

Goldingay, J 2015. An Introduction to the Old Testament: Exploring Text, Approaches and Issues. Downers Grove; IVP Academic

Hayes, JH. Understanding the Psalms. Forge: Judson Press

Hayes, J 1989. Interpretation, Psalms: A Commentary for Teaching and Preaching; Louisville: John Knox.

Idowu, B 1965. Towards an indigenous church. London: Oxford University Press

Knowles, MD 2014. "Feminist Interpretation of the Psalms". In Oxford Handbook of Psalms, edited by William P Brown, 425-444. Oxford: Oxford University Press.

Mandolfo, C 2014. "Language of Lament in Psalms". In The Oxford Handbook of the Psalms, edited by William P Brown, 114-121. Oxford University Press: Oxford. 
Masenya (ngwan'a Mphahlele), M 2014. “A Contextual Reading of Psalm 8" edited by Kenneth Mtata et al. In Singing the Lord's Songs in a Foreign Land. Leipzig: Evangelische Verlagsanstalt.

Mosala, IJ 1991. A Materialist Reading of the book of Micah. In Voices from the Margin: Interpreting the Bible in the Third World. Maryknoll; Orbis.

McCann, Jr 1993. A Theological Introduction to the Book of Psalms: The Psalms as Torah. Abingdon: Nashville.

McCann, JC 2014. "The Shape and Shaping of the Psalter: Psalms in their Literary. Context". In The Oxford Handbook of the Bible, edited by William P. Brown, 350-362. New York: Oxford University Press.

Murphy, RA 2000. The Gift of the Psalms, Peabody: Hendrickson Publishers.

Sneed, Mark R 2012. The Politics of Pessimism in Ecclesiastes: A Social Science Perspective. SBL: Atlanta.

Okorocha, C 2006. "Psalms". In Africa Bible Commentary, edited by Tokunboh Adeyemo, 605-746, Nairobi: WordAlive Zondervan Publishers.

Taylor, 1955. The Interpreter's Bible Volume IV. The Book of Psalms, The Book of Proverbs. New York, Nashville: Abingdon. 